\title{
痛覚誘発適刺激源としての Ar レーザの評価 ${ }^{*}$ 一皮膚加熱特性および安全性の検討一
}

\section{佐藤隆幸**, 福本一朗**}

Pain threshold measurements have been tried as the dosed energy density or the duration of stimulation time with a variety of thermal dolorimeters. However, the combination of a low-output Ar laser and a thermography enables to stimulate without contact and to measure the thresholds by skin temperatures. This paper propose the thermal pain threshold measurement system by this principle. We measure temperature thresholds on three subjects. As the results, the coefficients of variation in this technique are much smaller than ones in the traditional thermal dolorimeters and then it is suggested that the method in this study have a high reliability.

Additionally, the 2-dimensional heat transfer simulations are executed to estimate temperature on the surface and in the deeper part of the skin. The simulated results on the surface temperature fit well to the experimental value, and the results of deeper part of skin represent the efficiency of Ar laser in comparison with the case of $\mathrm{CO}_{2}$ laser stimulation.

従来熱痛計による痛覚闘值測定はエネルギー密度または刺激時間長をもって測定されてきた。しか し低出力の Arレーザとサーモグラフィとの組み合わせにより非接触刺激が可能となり, 皮膚温度に よる閥值計測が可能となった。我々はこの原理により熱痛闘值測定装置を構成し，3名の被験者を用 いて閾值温度を測定した。 その結果, 従来の熱痛計を用いた計測方法と比べて変動係数は非常に小さ く，本計測法が信頼性の高いものであることが示された．また皮膚表面および非侵襲的に測定するこ とのできない深部の温度分布について熱伝達シミュレーションにより予測を行った. 表面温度に関す る結果は実測值と概ね合致するものであり, 深部に関する結果からは $\mathrm{CO}_{2} レ$ レ゙との比較から $\mathrm{Ar} レ$ ーザの有効性が示された。

(キーワード：Arレーザ, 熱痛闒值, 熱伝達シミュレーション)

\section{1. はじめに}

痛みは温度感覚と共に種々の感覚のうち進化を示さ なかった原始的な感覚で侵害刺激から身体を守るため に必須の感覚である. 痛みは本来主観的な感覚量であ り，これを外部より直接測定することは現在のところ 不可能であるため, 1952 年の Hardyによる熱痛計開 発以来, 福本の改良型熱痛計など, ある量の痛刺激を

* 1996 年 9 月 2 日受付

** 長岡技術科学大学 工学部医用生体工学研究室 Laboratory of Biomedical Eng., Dept. of Eng., Nagaoka Univ. of Technology.
与えたときに被験者が痛みを知覚するか否かを調べて 痛覚閾值を測定する方法, すなわち閾値測定法がこれ まで用いられている11.

痛覚を誘発する上で適刺激の一つとされる熱による 方法は, 皮膚温度の監視・制御を伴う際にはその刺激 効果の恒常性が保たれやすい. 特に輻射熱による非接 触刺激を用いたときに得られる熱痛閾値は，圧覚ある いは触覚といつた機械的刺激要素が排除されており， 侵害受容神経活動の度合いをより正確に示すものであ ると考えることができる、このため近年，誘発脳波計 測時の刺激源としてレーザ光を用いた研究が数多く行 われている。

この用途としては皮膚に対して高い吸収特性をもつ 
光源として $\mathrm{CO}_{2}$ レーザが用いられることがあるが, こ れは表面から深さ $0.5 \mathrm{~mm}$ 程の範囲ですべて吸収され るために加熱部位が狭く，また温度上昇が急峻となる。 痛覚閾值測定は原則的に被験者の申告による方法をと るが, このとき皮膚温度の上昇過程において閾値への 到達・超過が急激であると被験者に退避の遅れを生じ させ，熱傷の原因ともなりかねない。またその場合， 申告遅れを生じて測定誤差の原因ともなる。このため 熱痛閾值測定の用途として考えた場合には，この特性 は熱源には適当であるとはいえない.

これまで我々は, 痛覚閾值測定には皮虐表面での吸 收特性が良好で, 熱症の危険性が低いと考えられる $\mathrm{Ar}$ レーザに着目してきた ${ }^{2 \sim 5}$. 熱痛閾值測定には大きい出 力を要さずに, 感覚受容器の存在する深さを適切な時 間をもって加熱する光源が適している，そこで我々は Arレーザがこれらの条件を満たす光源であることの 実験的証明を試みている.ただし, 皮膚に Arレーザを 照射した際の組織内の光強度および温度分布について 評価するには侵襲的な測定を必要とするが, 本研究で は計算機シミュレーションおよび Ar レーザ照射によ る発痛実験を実行し, その結果を用いて, $\mathrm{CO}_{2}$ レーザ との加熱特性の相違から熱痛閾值測定の熱源としての 有効性および安全性の検討を行う。

\section{2. 方 法}

\section{2-1. 皮膚熱伝達シミュレーション}

皮膚に対する加熱特性が未知である熱源に関してそ の有効性を検討する場合, 計算機シミュレーションを 用いた推測は組織内の温度分布の傾向を把握する上で 非常に有力である、レーザ照射時の生体組織内の温度 分布の計算には, 熱伝達と組織内光強度分布のそれぞ れについて記述する数值モデルが必要となるが, 本シ ミュレーションでは生体に関する熱伝達問題一般に用
いられる式(1)に示す熱伝達方程式, および式(2)に示す 光強度分布により組織内の温度分布を求める ${ }^{6)}$.

$$
\begin{aligned}
& \rho \mathrm{C} \frac{\partial \mathrm{T}}{\partial \mathrm{t}}=\nabla(\lambda \nabla T)-W_{b} C_{b}\left(T-T_{a}\right) \\
& +Q_{(z, r)} \\
& Q_{(z, r)}=Q_{0}\left[\exp (-\gamma z)+\frac{\beta}{2 \gamma} \cdot \gamma z \cdot \exp (-\gamma z)\right. \\
& \left.+\frac{\beta}{2 \gamma} \cdot \frac{\{1-\exp (-2 \gamma z)\}}{2}\right] \cdot \exp \left\{-\left(\frac{\gamma}{r_{0}}\right)^{2}\right\}
\end{aligned}
$$

ただし, 式(1)について $\rho$ は組織比重 $\left[\mathrm{kg} / \mathrm{m}^{3}\right], \mathrm{C}$ は組 織比熱 $[\mathrm{J} / \mathrm{kg} \mathrm{deg}], \mathrm{T}$ は組織温度 $\left[{ }^{\circ} \mathrm{C}\right], \lambda$ は組織熱 伝導率 $[\mathrm{J} / \mathrm{m} \mathrm{s} \mathrm{deg}], \mathrm{W}_{\mathrm{b}}$ は血流量 $\left[\mathrm{m}^{3} / \mathrm{kg} \mathrm{s}\right], \mathrm{C}_{\mathrm{b}}$ は 血液比熱 $\lceil\mathrm{J} / \mathrm{kg} \mathrm{deg}], \mathrm{T}_{\mathrm{a}}$ は血液温度 $\left[{ }^{\circ} \mathrm{C}\right], \nabla$ は微分 演算子, そして $\mathrm{Q}_{(\mathrm{z}, \mathrm{r})}$ はレーザパワー $\left[\mathrm{W} / \mathrm{m}^{2}\right]$. 式(2)に ついて $\mathrm{z}$ は組織表面からの光軸沿いの深さ $[\mathrm{m}], \mathrm{r}$ は 光軸からの距離 $[\mathrm{m}], \mathrm{Q}_{0}$ は光源出力 $\left[\mathrm{W} / \mathrm{m}^{2}\right], \gamma$ は 減衰係数 $=\alpha+\beta\left[\mathrm{m}^{-1}\right], \alpha$ は吸収係数 $\left[\mathrm{m}^{-1}\right]$, そして $\beta$ は散乱係数 $\left[\mathrm{m}^{-1}\right]$.

式(2)は深部方向への減衰を記述する Halldorsson の式と光軸からの離心方向への Gauss 分布を記述す る 2 つ式を乗じたものである.

皮膚モデルとしては図 1 に示すような，皮膚表面に 垂直に照射するレーザ光軸についてその進行方向，す なわち深部方向および側方向から成る断面の 2 次元モ デルを構成した。計算対象範囲は深部方向へ $10 \mathrm{~mm}$, 側方向へ両側 $5 \mathrm{~mm}$ とし,この範囲を 10,000 要素に分 割した有限要素的解法を用いている。この範囲を表面 から深部に向かって表皮, 真皮, 脂肪組織および筋肉 の 4 層に分割し，おのおのの光学的および熱的諸定数 は表 1 に従う7,8). 組織表面と接する周囲気温は実験施 行時に測定された $28.3^{\circ} \mathrm{C} と し$, また深さ $10 \mathrm{~mm}$ の温 度を $37^{\circ} \mathrm{C}$ 一定とした。それらの温度条件と $37^{\circ} \mathrm{C}$ 一定と 仮定した血流から中間部の温度分布を推測し, シミュ レーションの初期值とした.

表 1 は主に文献から皮膚に関しての值を得たもので

表 1 シミュレーションに用いた諸定数

Tab. 1 Coefficients used in simulation.

\begin{tabular}{c|c|c|c|c|c|c}
\hline 組織 (厚さ) & $\begin{array}{c}\text { 呼吸係数 } \\
{\left[\mathrm{m}^{-1}\right]}\end{array}$ & $\begin{array}{c}\text { 散乱係数 } \\
{\left[\mathrm{m}^{-1}\right]}\end{array}$ & $\begin{array}{c}\text { 熱伝導率 } \\
{[\mathrm{J} / \mathrm{m} \mathrm{s} \mathrm{deg}]}\end{array}$ & $\begin{array}{c}\text { 比重 } \\
{\left[\mathrm{kg} / \mathrm{m}^{3}\right]}\end{array}$ & $\begin{array}{c}\text { 比熱 } \\
{[\mathrm{J} / \mathrm{kg} \mathrm{deg}]}\end{array}$ & $\begin{array}{c}\text { 血流量 } \\
{\left[\mathrm{m}^{3} / \mathrm{kg} \mathrm{s}\right]}\end{array}$ \\
\hline 空気 & 0 & 0 & 0.026 & 1.165 & 1010 & 0 \\
\hline 表皮 $(0.5 \mathrm{~mm})$ & 3670 & 3670 & 0.498 & 1000 & 3500 & $2.49 \times 10^{-7}$ \\
\hline 真皮 $(1.5 \mathrm{~mm})$ & 1130 & 9080 & 0.498 & 1000 & 3500 & $2.49 \times 10^{-7}$ \\
\hline 脂肪 $(3.0 \mathrm{~mm})$ & 1130 & 9080 & 0.220 & 900 & 1300 & $4.20 \times 10^{-7}$ \\
\hline 筋肉 $(5.0 \mathrm{~mm})$ & 1120 & 53000 & 0.600 & 1020 & 3960 & $7.50 \times 10^{-6}$ \\
\hline 血液 & 12500 & 1500 & - & 1060 & 3500 & - \\
\hline
\end{tabular}


あるが, 皮膚血流に関しては身体部位や被験者, 姿勢 などの条件により変動が大きいものと考えられる。そ のため, 熱痛閾值測定実験を施行する直前に前腕掌側 で測定したものを計算に用いた，血流量の温度依存性 については加熱時間が数秒であるため考慮しない.

\section{2-2.Ａr レーザ照射による熱痛閾值温度 測定実験}

誘発電位を測定する目的に対しては，より純粋な信 号を得るために痛覚刺激は被験者において痛覚知覚過 程が無視できる程度に瞬時的なものが適する，柿木は 神経伝達速度が約 $10 \mathrm{~m} / \mathrm{s}$ であることを $\mathrm{CO}_{2}$ レーザを 用いた誘発電位実験にて測定している ${ }^{9)}$.この際の刺 激時間は 10〜20 ms としており，これは中枢への到達 時間約 $100 \mathrm{~ms}$ と比べて短く, 誘発電位の加算平均に よる特徴付けを容易にしている.

しかしながら, 被験者の申告をもって痛覚閵值温度 を測定しょうとした場合, 反応時間すなわち申告遅れ 時間の間の温度上昇が誤差として得られるため, 加熱 速度を臨界温度周辺において反応速度よりも十分に遅 いものとすることが望まれる.すなわち出力パワーに は目的に応じた上限が存在するが, 加熱熱源のレーザ 出力がある一定値以下であれば, 閾值温度をいつまで も超えないという基底值もまた存在する，上限値およ び基底值は共に初期皮膚温などによって変動するが, 刺激に用いるレーザ出力はこれらの值の間で設定する こととなる.

本実験では実験試行時の周囲気温 $28.3^{\circ} \mathrm{C}$, 湿度 66 \%の気象条件下において連続出力 $80 \mathrm{~mW}$ の Arレー ザを光源として用いた. なお光源については光線径 $1.5 \mathrm{~mm} \phi, \mathrm{TEM}_{00}$ モード, 主要波長は $488.0 \mathrm{~nm}$ およ び $514.5 \mathrm{~nm}$ で, フィル夕透過前の源出力 $4 \mathrm{~W}$ 時のパ ワー比にして $40 \%$ \%おび $33 \%$ \%゙ある.

閾値温度の本質は痛覚を発したときの受容器温度で あるが，これを非侵襲的に測定することは不可能であ る. そのため, 加熱箇所の皮膚表層での表面温度を受 容器の温度に近いものとして扱うこととなる. 本実験 での刺激対象となる自由神経終末は表皮組織に存在し， 被験部位とした前腕掌側においては深さ約 $0.05 \mathrm{~mm}$ 周辺に分布しているため ${ }^{10)}$ ，ここではサーモグラフィ 一により得られる皮膚表面温度を受容器のそれと同じ であるとみなすこととする。

本実験を行うために構成した測定系を図 1 に示す. 被験部位としては手掌や足底のような角質層の特に肥 厚した部位, 粘膜, あるいは体毛による遮光などの影 響が考えられる部位を避け, 計測が容易な前腕部掌側 を選択した。また上腕の圧迫により目視で確認される

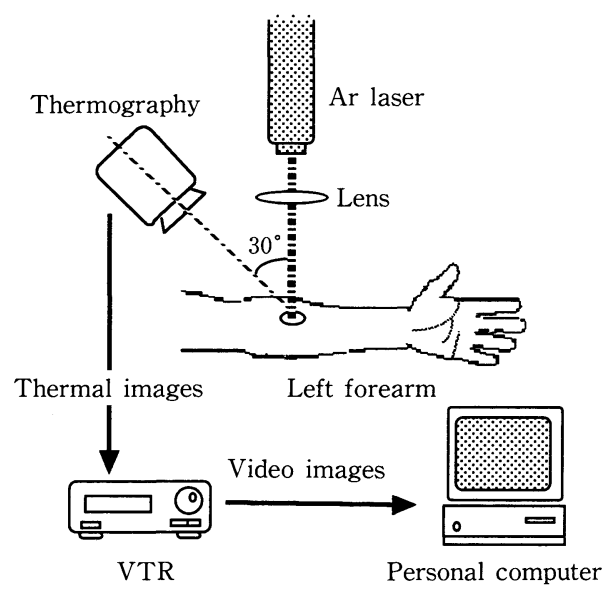

図 1 レーザ照射実験系

Fig. 1 System of the laser-irradiating experiments.

太い血管上を選択することも避けた．被験部位が光源 のArレーザ照射方向に対して直角となるょう位置決 めし, 温度上昇の様子は光軸に対し仰角 $30^{\circ} \mathrm{C}$ に設定し たサーモグラフィーにて観測する．得られた熱画像は VTR に格納した後, パーソナルコンピュータ上で解 析される.本システムでは時間分解能は約 $0.22 \mathrm{sec}$, 空 間分解能は約 $0.33 \mathrm{~mm}$ であった。

赤松は, 機械的痛覚間值の測定の際には刺激速度が 值に影響を及ぽすことを明らかとした ${ }^{11)}$.しかしレー ザ加熱による刺激の場合, 被験者あるいは被験部位に より加熱速度が異なる。このため, 刺激パワーを一定 として閾値に到達する時間をほほ同水準に保つことに より刺激速度の影響が除去されると仮定した。

また福本らは熱痛闇値測定中の一般的な被験者の内 省経過を「温感, 灼熱感を経た後, 明らかに刺痛とし て弁別できる痛みを生ずる」としている1)。ここではレ 一ザ照射開始から刺痛を生じて被験者が退避行動をと るまでの時間を閾値到達時間とし, そのときのレーザ 光照射中心の表面温度を閾值温度とした.

被験者は $23 \sim 26$ 歳 (平均 $24.3 \pm 1.5$ 歳) の神経生理 学的に特に異常の認められない健常な男性 3 名とし, 測定時の姿勢は直立位で, 測定側の前腕は体幹に対し てほほ直角となるよう台で支持した，前腕の静止は視 線の手掌付近への設定により維持し, 網膜保護のため に被験者にサングラスを装用させた。測定時刻は食後 の体温変動の影響を避けるため, 午後 $3 \sim 4$ 時に全測 定を行った。服装は T シャツ, ジーンズパンツおよび ソックス $(0.5 \mathrm{clo})$ で統一した.

測定回数は 1 被験者あたり 5 回とし, 熱傷や順応・ 感作を起こさないよう, 半径 $1 \mathrm{~cm}$ の円内において試 行毎に位置を変えて測定を行った。また時間間隔は約 
表 2 レーザ照射による発痛実験結果

Tab. 2 Results of pain-generating experiments by Ar laser irradiation.

\begin{tabular}{c|c|c|c|c|c|c}
\hline \multicolumn{2}{c|}{} & $\begin{array}{c}\text { 被験者 } \\
1\end{array}$ & $\begin{array}{c}\text { 被験者 } \\
2\end{array}$ & $\begin{array}{c}\text { 被験者 } \\
3\end{array}$ & $\begin{array}{c}\text { 全試行間 } \\
(\mathrm{n}=15)\end{array}$ & $\begin{array}{c}\text { 変動係数 } \\
{[\%]}\end{array}$ \\
\hline \multirow{2}{*}{$\begin{array}{c}\text { 閾値到達 } \\
\text { 時間 }[\mathrm{sec}]\end{array}$} & 平均 & 3.61 & 3.08 & 5.90 & 4.19 & \multirow{2}{*}{38.9} \\
\cline { 2 - 6 } & 標準偏差 & 1.85 & 0.34 & 0.39 & 1.63 & \\
\hline $\begin{array}{c}\text { 閾値温度 } \\
{\left[{ }^{\circ} \mathrm{C}\right]}\end{array}$ & 平均 & 41.9 & 41.8 & 41.3 & 41.7 & \multirow{2}{*}{2.3} \\
\cline { 2 - 6 } & 標準偏差 & 1.24 & 1.04 & 0.63 & 0.97 & \\
\hline
\end{tabular}

3 分とした.

\section{3. 結 果}

\section{3-1. 熱痛閵值温度測定結果}

レーザ照射による発痛実験において得た熱痛発生時 間とそのときの皮膚温度との関係を表 2 および図 2 に 示す.

被験者 1 による測定結果は閾値到達時間において大 きくばらつくものであり，その度合いは標準偏差の比 較からも他の被験者とは異なる。被験者 1 は闘值温度 においても標準偏差が最も大きいが，これは図 2 から もわかるように第 4 試行目の両値がその前後の試行で の值の分布帯から顕著に逸脱していることに起因する ものである.

本論文では痛覚閾值を示すパラメータとして閾値到 達時間および閾值温度を測定したが，各被験者間の光 学的あるいは熱的特性の相違による皮膚組織加熱速度 の差を反映してか, 前者は被験者間の平均値の差が大 きく得られた。一般に測定単位の異なる集団間のばら つきの比較に, 標準偏差と平均值の比を百分率で表し た変動係数 (coefficient of variation：CV) が用いら れる.この係数において閥值温度のばらつきは閾値到 達時間の約 $1 / 17$ の水準として得られ, 熱痛闘值のパラ メータとしてこれを用いることで適切な加熱制御を行 う際の精度の高い指標となることが考えられる。

従来の熱痛計を用いた測定方法によれば，同一被験 者内変動および被験者間変動は Hardy の熱痛計で 5 \%および $15 \%$ ，福本の改良型熱痛計で $5 \%$ および 18 \%であるが1)，ここで得られた変動係数は共に $3 \%$ 以 内であり，パラメー夕を温度とした有効性が示された。

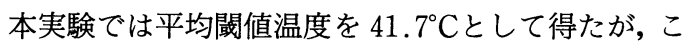
れと Hardy が前腕部のものとして測定した $44.3^{\circ} \mathrm{C}$ と

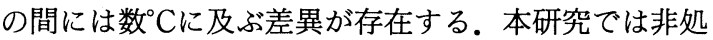
理の皮膚表面の温度を, Hardy は皮膚上に塗付した黒 色塗料の温度をそれぞれ用いて閾值としている。

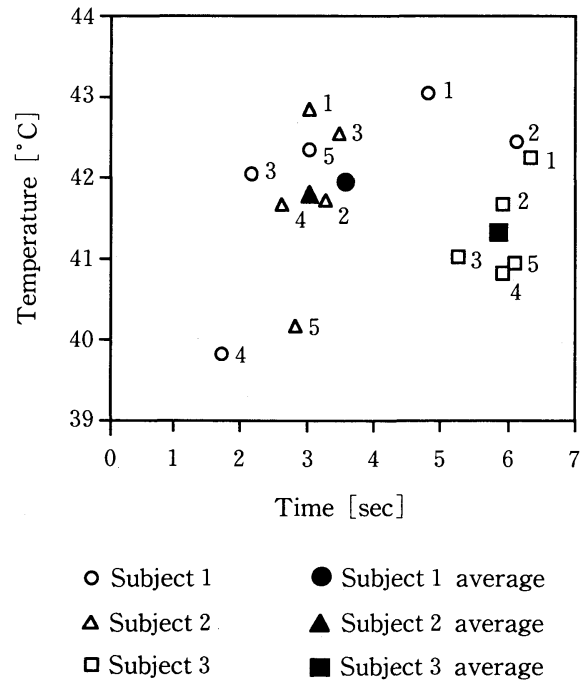

図 2 閥値到達時間一閾値温度の相関分布

Fig. 2 Correlation distribution between threshold reaching time-threshold temperatures.

Hardy の方法によれば，輻射吸収した黒色塗料が平面 接触熱源として機能すると考えられる。熱源一受容器 間には温度勾配が存在し，受容器を閾值温度へ導く熱 源温度が閥值として測定されるため, 結果として高い 閾値が得られることになる.今後このような測定原理 に由来する值の差を定量的に明らかとする必要がある.

\section{3-2. 皮掂表面温度の時系列変化}

図 2 に示すとおり全試行 $(n=15)$ において閾值到達 時間は $1.76 \sim 6.38$ 秒の間で得られた.この間の全試行 についての皮膚表面温度の経時変化の平均曲線および シミュレーションによる温度上昇曲線は図 3 のように なる。

前者は照射時間すなわち閾値到達時間が各試行間で 異なるため, 曲線上の各值が導き出される標本数は互 いに異なる、シミュレーションによる計算結果の曲線 は各試行における個々の温度上昇曲線との間では傾き 


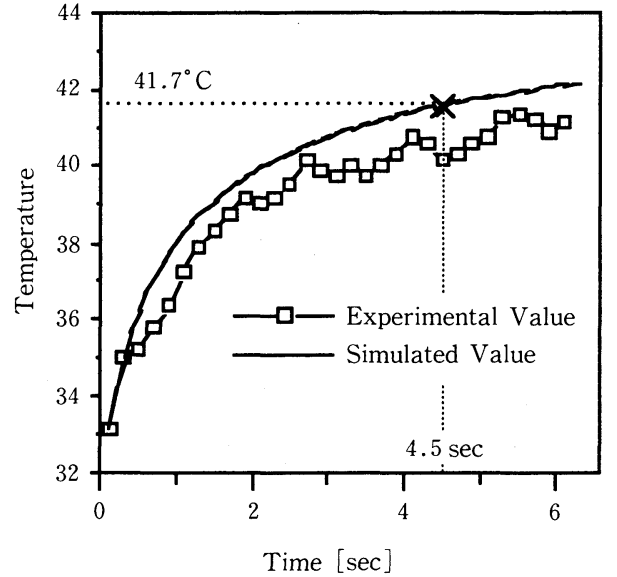

図 3 レーザ照射中の皮膚表面温度の時系列変化

Fig. 3 Changes in time course of the skin surface temperature during the laser irradiations.

に差がみられたが，実測值の平均曲線とは概ね同様の 傾向として得られた。このことは, 本シミュレーショ ンが皮膚表面についての計算に関しては妥当性を持ち, またここで用いた表 1 で示す種々のパラメータが熱痛 闘值温度測定実験に用いた被験者の光学的・熱的パラ メータの平均値と程近いことを示す。

実測値と計算值との間の差異には幾つかの要因が考 えられるが, 画像処理過程において観測された表面温 度分布の変動要因について付記しておく. 図 1 で示さ れる測定系を用いて得られる熱画像において, 表面温 度の 2 次元分布は中心を最大值とする円形とならず, 最大温度点は最大 $3 \mathrm{~mm}$ 程度 2 次元的に変動すること が観測された。この間の体動は前腕掌側に張り付けた アルミ箔片により観察したが，ほとんど見受けられず， 被験者により程度が異なるもののこの 2 次元的変動は すべての試行でみられた。

また本実験の測定系評価のために食用八厶を試料と して予備実験を行ったが，このような変動は観測され ず, 光源光学系の振動などの影響は存在しないと考え られる. 主要な変動因子としては, 皮膚表面の血流の ベクトル性をあげることができるが, シミュレーショ ンのアルゴリズム中では血流をスカラ量として扱って いるため, 計算結果に若干の差が生じ得る.

\section{3-3. シミュレーションによる熱痛闘值}

\section{発生予測}

熱痛閾値は熱傷発生開始の臨界温度点であると考え ると，その計測に際してはエネルギー出力および照射 時間で決定される印加刺激量の制御により, 発痛およ び過加熱抑止を行うことが望まれる。
本研究で開発した熱伝達シミュレーションを用いて 閾值発生時間を予測した結果を図 3 上に示す。熱痛閾 値測定実験により得た閾値温度 $41.7^{\circ} \mathrm{C}$ を得るために 要する時間は 4.5 秒と計算され, 閾值到達時間の平均 值 4.19 秒と幾分かの差異が存在する.この時間差の間 の温度上昇を求める手段として, 簡易的に図 3 の実験 値曲線を対数関数と見なすと $\mathrm{y}=4.94 \log \mathrm{x}+32.46$ として得られる.これから $\mathrm{t}=4.19 \sim 4.50$ [sec] の間 の温度上昇分，すなわち熱症発生に関する温度予測誤 差を計算すると $0.35^{\circ} \mathrm{C}$ となる。このたびの実験で得ら れた平均曲線の回帰曲線上においては，この増加分は 安全性の見地からも大きなものではない. しかしなが ら, 温度上昇速度は被験者あるいは試行により異なる ため,レーザによる痛覚誘導の際の安全性確保のため には, 皮膚へのレーザ照射時の温度をリアルタイムで 測定し, 実験值の回帰曲線あるいはシミュレーション 曲線へのフィッティングから痛覚および熱傷発生の予 測が可能となるよう, 今後の検討が必要である.

\section{3-4. 熱伝達シミュレーションによるレーザ照 射時の皮席内部温度推定}

皮膚組織の内部温度は侵襲を伴わずに測定できない ため, 本実験では表面温度のみに着目して評価を行っ てきた. しかし, 表面以深で最高温度点が存在するの なら表面温度を閾值温度とし, 安全性確保のパラメー 夕とすることは妥当ではない. 深部方向への温度分布 を調査するにあたり実測は侵襲を伴い，また連続的に 細部まで測定することは困難であるため, シミュレー ションにより推測する方法が有効である.

本実験で用いた光源により作り出される光軸上の深 部方向への温度分布についてシミュレートした結果を 図 4 に示す．表面からの空気への熱伝達により最大温 度点は表面要素とはならず, この傾向は加熱時間の増 加に伴い強くなる. しかし, 加熱時間を 10 秒とした場 合でも表面と最高温度点との温度差は $0.2^{\circ} \mathrm{C}$ 程度であ り, 表面温度の観測により皮膚組織の安全管理は精度 よく行うことができる可能性が示唆される.

このシミュレーションを利用して，柿木による $\mathrm{CO}_{2}$ レーザを用いた痛覚刺激方法の温熱的評価を行う。誘 発脳波取得を目的とした刺激は本実験でのそれとは異 なり, 瞬時的な温度上昇が適している. 柿木は光線径 $2 \mathrm{~mm} \phi$ の $\mathrm{CO}_{2}$ レーザを刺激時間 $10 \sim 20[\mathrm{~ms}]$, 照射量 を $18\left[\mathrm{~mJ} / \mathrm{mm}^{2}\right]$ として手背への刺激を行っている. この条件をシミュレーション上で実現し,さらに照射 終了後 3 秒間の皮膚表面温度の変化を時系列で示した ものが図 5 である．ただし，初期の皮膚表面温度，周 囲気温あるいは皮膚各層の厚さなどについては本研究 


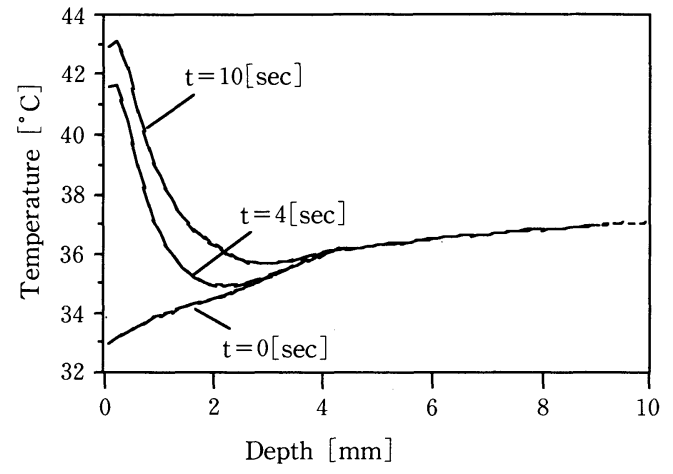

図 4 Arレーザ照射による深部温度分布の時間変化のシ ミュレーション結果

Fig. 4 Simulated results of changes in distributions of deeper part temperatures with time of Ar laser irradiation.

中でのものと同一とし，また表皮での吸収係数を $200\left[\mathrm{~m}^{-1}\right]$, 散乱係数を $0\left[\mathrm{~m}^{-1}\right]$ とした. $\mathrm{CO}_{2}$ レーザ の照射により表面温度は急速に上昇して $100^{\circ} \mathrm{C}$ 付近ま で到達し, 照射 0.5 秒後には閥值温度以下にまで下降 している．柿木は試行間の時間を慣れの影響を考慮し て 3 秒としたが，この間隔は温熱的見地からも適切で あるといえる。

また同様にシミュレーションの手法を用いて深部方 向への熱伝達についても調査した (図 6 ).この結果か ら, レーザ照射直後の分布と比べ, 3 秒後には熱伝導 の影響で梁さ $0.5 \sim 1.0 \mathrm{~mm}$ 付近で若干高くなってい るものの, 血流および空気への熱放散によりほほ加熱 前の温度分布まで冷却されていることがわかる.

$\mathrm{Ar}$ レーザの皮膚組織加熱特性との比較から, $\mathrm{CO}_{2}$ レーザはより急峻でかつごく表層において高温部位を 作り出すことがわかる. 熱痛間值測定の際の熱源とし て $\mathrm{CO}_{2}$ レーザを用いた場合には, 被験者がその温度上 昇過程を十分認知することができず, 正確な閾值温度 の測定は困難であるため, 本目的に対する低出力領域 の Arレーザの有効性が示唆される.

\section{3-5. Ar レーザ照射による痛覚誘導に関する 安全性の検討}

本研究では低出力領域の Ar レーザを発痛熱源とし ているが，今後痛覚に関する臨床実験を継続していく 上で，その安全性について検討をしておく必要がある.

ANSI で設けてある安全基準によれば，皮膚に対す る可視光の $10^{-3} \sim 10$ 秒の照射の際の総照射量は $1.1 \times 10^{-2} \mathrm{t}^{1 / 4}\left[\mathrm{~J} / \mathrm{mm}^{2}\right]$ で表せ ${ }^{12)}$, 本実験での照射条件 をこれに適用すれば，基準值は $6.58 \times 10^{-2}\left[\mathrm{~J} / \mathrm{mm}^{2}\right]$

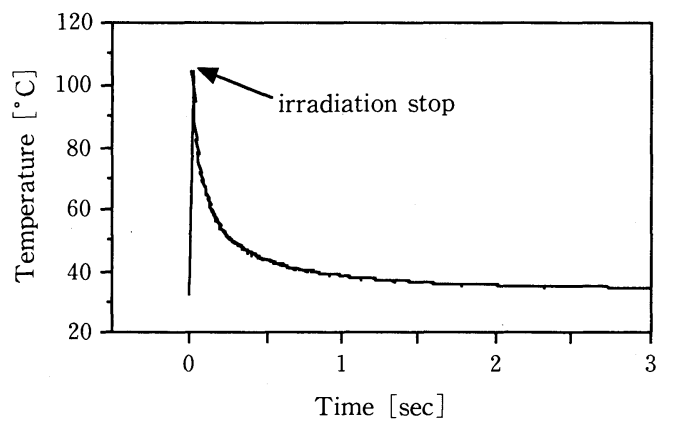

図 $5 \mathrm{CO}_{2}$ レーザによる痛覚誘導時の表面温度の経時変化 を示すシミュレーション結果

Fig. 5 Simulated results of changes in time course of the skin surface temperature during the pain-inducing experiments by $\mathrm{CO}_{2}$ laser.

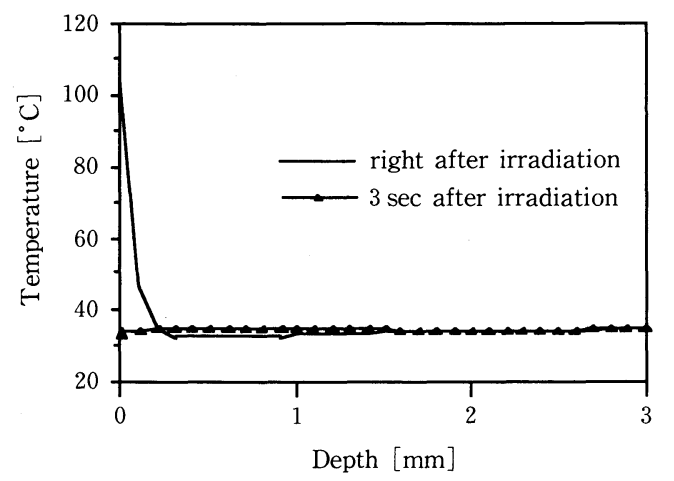

図 $6 \mathrm{CO}_{2}$ レーザ照射時間による深部温度分布の変化に関 するシミュレーション結果

Fig. 6 Simulated results of changes in distributions of deeper part temperature with time of $\mathrm{CO}_{2}$ laser irradiation.

となる。ここで用いたレーザ光強度は $1.13 \times 10^{-2}[\mathrm{~W} /$ $\left.\mathrm{mm}^{2}\right]$, 平均照射時間は 4.19 秒であり, すなわち平均 総照射量は $4.73 \times 10^{-2}\left[\mathrm{~J} / \mathrm{mm}^{2}\right]$ と求められ, これは 安全基準内である. 可視領域のレーザ光線の生体組織 への作用はほほ熱的なものであることが知られてお $\eta^{12)}$ ，またここでの実験後の被験部位にも熱傷などは 見受けられなかった. しかしながら, より頻回の同一 部位への刺激による病理的変化については明らかとし ておらず，今後より詳細な安全性の評価が必要である.

\section{4. まとめ}

Arレーザを照射した際の痛覚発生および皮膚表面 の温度変化について被験者 3 名を用いた実験を行い, 閾値温度を $41.7 \pm 0.97^{\circ} \mathrm{C}$ して得た。被験者間あるい 
は同一被験者内においてばらつきが小さかったことか ら, 従来の熱痛閾値のパラメータとして用いられてい たエネルギー投与量あるいは刺激時間と比べて皮膚表 面温度はより正確な指標であることが示された。

本研究において開発した熱伝達シミュレーションは, 調査時間内において実験結果に概ね追随するものであ った。しかし, 実験データの熱画像は加熱範囲が 2 次 元的に微動するものであったため, これを加算平均処 理して得られた実測曲線はその影響を誤差因子として 内包するものである.

痛覚誘導の目的で用いられる $\mathrm{CO}_{2}$ レーザの作り出 す皮膚温度分布について，シミュレーションを用いて 評価を行ったところ, ごく表層を急峻に加熱するため, 閾値温度測定の目的には適さないことがわかった。

Arレーザの照射による痛覚誘導の安全性について, ここで行った実験後の観察とANSI の安全基準との 比較により検討を行った。実験後の障害は何ら起こら ず，また照射量も基準值を下回るものであった．今後 は同一部位への頻回の照射による安全性についても評 価を行っていく必要があると考えている.

\section{参考文献}

1）福本一朗：痛みの定量化, 人間工学, $8(6)$, 325 331, 1982.

2）佐藤隆幸, 福本一朗 : レーザ熱痛計の基礎研究, 豊田研究報告, 41〜 46, 1993.

3）佐藤隆幸，福本一朗：低出力レーザの皮膚組織 加熱効果に関する計算機シミュレーション, 長岡 技術科学大学研究報告, 15，65～69，1993.

4）佐藤隆幸, 福本一朗：レーザ熱痛計の基礎研究,
電子情報通信学会技術研究報告, 93(356), 1 6, 1993.

5) Takayuki Satoh, Ichiro Fukumoto: Basic Studies of Thermal Dolorimeter, Abstract of the Worl Congress on Medical Physics and Biomedical Engineering, 139, 1994.

6) T. Halldorsson, J. Langerholc: Thermodynamic analysis of laser irradiation of biological tissue, Applied Optics, 17 (24), 3948 〜3958, 1978.

7) Wai-Fung Chong, et al. : Optical Properties of Biological Tissues, IEEE J. Quantum Electronics, 26 (12), 2166 2185, 1990.

8) Peter M. Van den Berg, et al.: A Computational Model of Electromagnetic Heating of Biological Tissue with Application to Hyperthermic Cancer Therapy, IEEE Transactions on Biomedical Engineering, BME-30 (12), 797〜805, 1983.

9）柿木隆介：痛覚刺激, 臨床脳波, 34(3), 199 205，1992.

10）赤松幹之：皮膚弾性モデルによる痛覚受容の計 算器シミュレーション, 医用電子と生体工学, 22 (3), 186〜193, 1984.

11）赤松幹之：針の押込み量をパラメータとした痛 覚閾值測定, 医用電子と生体工学, $21(6)$, 465 471，1983.

12）福本一朗：医用レーザ安全の基礎, 臨床検査, 33 (13), 1785 1793, 1989. 